\title{
MODELLING AND SIMULATION OF DISPERSIONS OF POWDER EMISSIONS FROM MULTIPLE SOURCES WITH THE MATHEMATICAL MODEL POL 15SM
}

\author{
Mihaela Budianu ${ }^{\mathrm{a}}$, Valeriu Nagacevschi ${ }^{\mathrm{b}}$, Matei Macoveanu ${ }^{\mathrm{b}}$ \\ ${ }^{a}$ Environmental Protection Agency Vaslui, Str. Calugareni, no.63, 730149 Vaslui, Romania \\ ${ }^{b}$ Department of Environmental Engineering and Management, Faculty of Chemical Engineering, \\ Technical University of Iasi, 71A D. Mangeron Bd., 700050 Iasi, Romania
}

Submitted 16 Feb. 2012; accepted 25 Jun. 2013

\begin{abstract}
Over the last decades, air pollution has become one of the greatest challenges negatively affecting human health and the entire environment, including air, water, soil, vegetation, and urban areas. Lately, special attention has been given to mathematical modelling for diffusion of pollutants in the atmosphere as a particularly effective and efficient method that can be used to study, control and reduce air pollution. The diversity of models developed by different research groups imposed a rigorous understanding of model types in order to apply them correctly according to local or regional problems of air pollution phenomenon. Thus the authors have developed and improved two mathematical models for dispersion of air pollutants. This paper presents a case study of dispersion of powders in suspension originating from 14 point sources that correspond to 5 economic agents in the agroindustrial area of Vaslui city using a computer simulation based on the mathematical model Pol 15sm, for multiple point sources of pollution, designed by the authors.
\end{abstract}

Keywords: pollutant dispersion, dispersion models, air pollution, suspended powders, heavy metals, computer simulation.

Reference to this paper should be made as follows: Budianu, M.; Nagacevschi, V.; Macoveanu, M. 2014. Modelling and simulation of dispersions of powder emissions from multiple sources with the mathematical model Pol 15sm, Journal of Environmental Engineering and Landscape Management 22(02): 151-160.

http://dx.doi:10.3846/16486897.2013.821068

\section{Introduction}

Lately, a special attention has been given to studying the dispersion of pollutants emitted into the atmosphere by multiple or isolated pollution sources, operating continuously or accidentally, as it is increasingly evident that human activities have already produced a "disturbance" of the environmental balance (Carpentieri et al. 2011; Hanna 1981; Huang et al. 2011; Mezdrea-Cojocareanu-Pata et al. 2010; Miclaus et al. 2006).

Atmospheric emissions of heavy metals are deposited in the form of suspended powders on the ground at varying distances from the emission source, distances that depend on particle sizes and the intensity of air currents (Radulescu et al. 2010). Problems related to the presence in the environment of metallic elements in the environment are triggering a growing interest (Nisulescu et al. 2011; Stătescu, Cotiuşcă-Zauca 2006).

Areas with heavy metals contaminated soils around the industrial units differ in expansion due to intensity and duration of emissions, weather and geomorphologic aspects (Baldauf et al. 2009; Carpentieri et al. 2011; Gaba 2010; Miclaus et al. 2006).

In Romania, the calculation of pollutant emissions into the atmosphere is reflected in the methodology EEA/ EMEP/CORINAIR and U.S. EPA/AP-42 for all business groups, including industrial point sources.

One way of knowing and subsequently taking action against air pollution is the mathematical modelling of pollutant dispersion into the atmosphere (Hanna 1981; Vătăşescu et al. 2011; Ani et al. 2012). This consists of

Corresponding author: Matei Macoveanu

E-mail: matei_macoveanu@yahoo.com 
estimating pollutants concentrations on soil and height accordingly with pollution sources characteristics, weather and geographic conditions, physical and chemical transformation processes that pollutants might have in the atmosphere and their interaction with the soil surface (Baldauf et al. 2009; Budianu, Macoveanu 2010; Carpentieri et al. 2011).

Insidious effects on medium and long term, regionally and even worldwide, can be caused by local polluting phenomena from a variety of "quasi-harmless" point sources. Considering them, especially in the last 30 years, scientific efforts have focused on detailed studying of transport and dispersion mechanisms of pollutants into the atmosphere and the consequences of these phenomena, without neglecting the measurement techniques of pollutants at source, adapted to various situations (Branquinho et al. 2008; Hanna 1981; Nisulescu et al. 2011; Stefan et al. 2013). The development and importance of mathematical models of pollutant dispersion are presented widely in specialized literature. Of the many models studied, four main types of models are distinguished: statistical/empirical, Gaussian (most used), Lagrangian and Eulerian (most complex) (Candelieri et al. 2012; Moreira et al. 2010; Pasquill 1961; Popescu et al. 2011; San Jose 1997; Smaranda, Gavrilescu 2008).

After analyzing these models, assessing the advantages, disadvantages, features, limitations and accessibility degree offered, computer simulations based on the mathematical models ECO95sp and Pol 15sm were used to calculate the pollutant dispersion in the atmosphere of Vaslui city (Nagacevschi, Macoveanu 1994, 1995, 1996, 2002; Nagacevschi et al. 1997).

The paper presents a case study on dispersion modelling of suspended powders emitted jointly by many point sources in the agroindustrial area of Vaslui, with calculating pollutant concentrations on immission for several set receptors, using Pol $15 \mathrm{sm}$ model.

\section{Description of mathematical model POL $15 \mathrm{sm}$ and the accordingly simulation program}

Using this Gaussian model for studying the dispersion of pollutants emitted by multiple sources is possible, continuing the study of pollutant dispersion originating from each individual point source, done using ECO95sp model. This is a logical follow-up of the fact that these 2 models have a complementary character; in addition, both use the same type of classification of atmospheric stability, the same division into 2 distinct types of terrain and, broadly, the same input requirements.

Like the mathematical model ECO95sp, Pol 15sm is a model for calculating dispersion of pollutants into the atmosphere, developed and tested as a computer simulation program in the Department of Chemical
Engineering and Environmental Protection of Chemical Engineering and Environmental Protection Technical University "Gheorghe Asachi” of Iasi.

POL $15 \mathrm{sm}$ model is the base of a simulation program of concentration distribution for a pollutant emitted by several sources, well located, to a number of pollution receptors, also precisely located:

- maximum number of emitting point sources that the program can take into account - 15;

- maximum number of receptors that can be considered -15 .

Performances of the model can be best summarized by specifying the types of outputs; at each receiver point the following output are measured and played in the form of data:

- local concentration of pollutant due to emission of each source;

- total local concentration of pollutant, emitted by all sources considered;

- average local concentration, in the time interval of interest, due to each emission source;

- total average local concentration, in the time given.

Note that the first two categories of results are given periodically, with a period of maximum 15 hours, the modelling assumption formulated being that the average frequency weather changes is also periodically.

The stages of rolling are the classic ones, while the input required by $\mathrm{Pol} 15 \mathrm{sm}$ model needs:

- data describing the characteristics of each emission source in part (mass flow of pollutant emitted, total volumetric flow of exhaust gases, exhaust gas temperature, physical height of pollutant source, source coordinates to a fixed reference point);

- data describing the receptors considered (the number of receptors to pollutant immission concentration taken into account, the height of placement of every receptor considered, landmark coordinates to a fixed point, the nature of land);

- climatologically data (weather conditions, wind speed, air temperature).

To describe the model, it is said that both the input and the output are presented in tables in type ASCII text files: "POL.DAT" - for input data and "POL.REZ" - for output data. In term of input data required by the Pol $15 \mathrm{sm}$ model, these can be grouped in three categories:

a. "Sources" (valid for each emission source)

$n_{s}=$ number of emission sources considered $\left(n_{s}\right.$ $\max .=15$ );

$Q=$ mass flow of pollutant emitted $(\mathrm{mg} / \mathrm{s})$;

$Q_{f}=$ volumetric flow of "smoke" at emission (total gas flow emitted by each source), $\left(\mathrm{m}^{3} / \mathrm{s}\right)$;

$T_{f}=$ temperature of "smoke" at emission (exhaust gas temperature), $\left({ }^{\circ} \mathrm{C}\right)$;

$h=$ physical height of pollutant source, (m). 
Sources coordinates set to a fixed reference point, were chosen accordingly:

- cxs = West-East coordinate, $(\mathrm{m})$;

$-c y s=$ South-North coordinate, $(\mathrm{m})$.

b. "Receptors" (valid for each receptor)

$n_{r}=$ receptors number of pollutant concentration considered at emission $\left(n_{r} \max .=15\right)$;

$z=$ height of every receptor considered, (m).

Receptors coordinates, to the same fixed reference point chosen:

- cxs = West-East coordinate, $(\mathrm{m})$;

- cyr = South-North coordinate, (m).

"Rural / Urban" = option regarding the terrain conditions for each source

c. "Hourly weather conditions"

$n_{o}=$ number of considered hours $\left(n_{o} \max .=15\right)$;

$u=$ wind speed, $(\mathrm{m} / \mathrm{s})$;

$\theta=$ wind direction, from North, measured clockwise, (degrees);

$(1-6)=$ class selected to define the atmospheric conditions (using all 6 Pasquill stability classes, as in the case of "ECO95sp" model);

$T=$ atmospheric temperature, $\left({ }^{\circ} \mathrm{C}\right)$.

To facilitate the use of the simulation program by people who do not have sufficient knowledge regarding the characterizing criteria stability/atmospheric turbulence state, within the program recommendations are stated regarding choosing classes for weather conditions, with values from " 1 " to " 6 ". Thus, we considered I-VI cases, characterized below by the following conditions:

- case I - day, sun shining brightly, solar radiation within an angle wider than $60^{\circ}$;

- case II - day, sun shining moderately, solar radiation within an angle between $35^{\circ}$ and $60^{\circ}$ (so-called the "slightly covered" sky);

- case III - day, sun shining weakly, solar radiation within an angle slighter than $35^{\circ}$ ("partially covered" sky);

- case IV - day/night (night/day) interval, cloudy sky

- case V - night, cloudy sky (cloudiness over 50\%);

- case VI - night, partially cloudy sky (cloudiness below $50 \%$ ).

Then, the appropriate class for characterization of certain atmospheric conditions is set, accordingly with the specifics of every situation of dispersion modelling considered, using Table 1.

Note that in the case of this model also, the value "1" (or "A") corresponds to the category "Highly unstable", and the value " 6 " (or "F") corresponds to the category "Highly stable", according to the classification made by Pasquill (1961).

In the input data for this program the main geographical characteristics (natural or anthropic) are not found. These can influence the dispersion of pollutants emitted in the atmosphere from a given source and they are:

- significant bumps of the terrain, located in the main propagation direction of the pollutant plume (geological formations of hill, mountains, deep and narrow valley, etc.);

- the existence in the area of significant water courses, lakes of important volume and surface, rich in vegetation areas (e.g. forests), whose presence somehow influence the micro-climate of areas more or less extensively;

- the presence, near the source, of constructions of important dimensions, especially in terms of height, which can induce local changes of direction and even speed of air flow with a role in training and dispersal of pollutants.

Unlike the U.S. AERMOD model, which is a model that applies to industrial sources and of the last generation, that already contains principles of planetary boundary layer, and Pol $15 \mathrm{sm}$ is a much simpler, easy to use software that requires no complex and expensive sites.

There are two input data processors that are regulatory components of the AERMOD modelling system: AERMET, a meteorological data preprocessor that incorporates air dispersion based on planetary boundary layer turbulence structure and scaling concepts, and AERMAP, a terrain data preprocessor that incorporates complex terrain using USGS Digital Elevation Data. Other non-regulatory components of this system include: AERSCREEN, a screening version of AERMOD; AERSURFACE, a surface characteristics preprocessor, and BPIPPRIME, a multi-building dimensions program incorporating the GEP technical procedures for PRIME applications.

For Pol 15sm program selection in order to apply it with conclusive results for an industrial area (only for industrial point sources) a number of specific criteria were taken into account:

Criteria for the weather:

- the presence of atmospheric calm periods in over $24 \%$;

- significant frequency of total and partial thermal inversions;

- the existence of periodic winds (NW and $\mathrm{N}$ wind);

- relatively high humidity conditions (favoring the occurrence of side effects for pollutants emitted).

Criteria for relief conditions:

- location in the Bârlad valley area - relatively flat surface;

- proximity to the relief of sub-Carpathians, with heights not exceeding $400 \mathrm{~m}$ and below $150 \mathrm{~m}$ altitude difference from the platform.

Criteria regarding emissions:

- the existence of emission sources with significantly different heights (between $12 \mathrm{~m}$ and $218 \mathrm{~m}$ ); 
- the existence of industrial buildings and constructions of moderate size, in the vicinity of emission sources of medium height, but at distances for which the existence of the building is not appreciated;

- different exhaust emissions, in favorable conditions, can lead to secondary reactions into the atmosphere, as the formation of another pollutant.

\section{Other criteria:}

- the importance of extending the assessment area within a radius of at least $40 \mathrm{~km}$ (to the border with Moldova);

- the opportunity to formulate conclusions based on modelling results, and consequences of historical pollution (e.g. damage quantification of buildings and civil engineering, possibly while assessing the impact on current health and the integrity of ecosystems potentially affected);

- the availability of models, both financially (since most of these models are only the demonstration, completing their purchase involves payment of substantial amounts) and in terms of logistics resources to be mobilized for their use.

The underlying mathematical model to the simulation program Pol $15 \mathrm{sm}$, to calculate the dispersion of emitted pollutants into the atmosphere from multiple point sources, is described below:

1. Calculation of source - receptor distance in wind direction:

$$
\begin{gathered}
x_{r e l}=c x r_{j}-c x s_{i} ; \\
y_{r e l}=c y r_{j}-c y s_{i} ; \\
x=x_{r e l} \cdot \cos \left(\theta_{k}\right)+y_{r e l} \cdot \sin \left(\theta_{k}\right) ; \\
y=\sqrt{\left(x_{r e l}^{2}+y_{r e l}^{2}-x^{2}\right)},
\end{gathered}
$$

$c x r=$ West-East Cartesian coordinate, for receptors, $(\mathrm{m})$; $c y r=$ South-North Cartesian coordinate, for receptors, $(\mathrm{m})$; $c x s=$ West-East Cartesian coordinate, for point sources, (m);

$c y s=$ South-North Cartesian coordinate, for point sources, (m);

$i=$ current point sources number; $j=$ current receptors number of pollutant concentration at imission considered;

$\theta=$ wind direction, from North, measured clockwise, (degree);

$x r e l, y r e l=$ Cartesian projections of point source to receptor distance, $(\mathrm{m})$;

$x, y=$ projections of point source to receptor distance, on wind direction, $(\mathrm{m})$.

2. Calculation of pollutant dispersion into the atmosphere:

$$
\begin{aligned}
& \sigma_{y}=f_{1}(x, k) ; \\
& \sigma_{z}=f_{2}(x, k),
\end{aligned}
$$

$\sigma_{y}, \sigma_{z}=$ pollutant dispersion on $y, z$ directions, respectively.

3. Calculation of smoke plume height:

$$
\begin{gathered}
d h=f_{3}(x, k, i) ; \\
H_{t}=h_{0}+d h,
\end{gathered}
$$

$H_{t}, h_{0}, d h=$ height of pollutant smoke plume (total, initial, increment), (m).

4. Calculation of concentration at receptor:

$$
\begin{aligned}
& \psi_{i, j, k}=\frac{Q}{2 \pi \cdot \bar{u} \cdot \sigma_{y} \cdot \sigma_{z}} e^{-0,5\left(\frac{y}{\sigma_{y}}\right)^{2}} . \\
& {\left[e^{-0,5\left(\frac{z-H t}{\sigma_{Z}}\right)^{2}}+e^{-0,5\left(\frac{z+H t}{\sigma_{Z}}\right)^{2}}\right],}
\end{aligned}
$$

$-Q=$ mass flow of pollutant emitted $(\mathrm{mg} / \mathrm{s})$;

$-u=$ wind speed, $(\mathrm{m} / \mathrm{s})$.

5. Calculation of averaged concentration:

$$
\begin{aligned}
& \bar{\Psi}_{j, k}=\frac{1}{n_{i}} \sum_{i}^{n_{i}} c_{i, j, k} ; \\
& \bar{\psi}_{i, j}=\frac{1}{n_{k}} \sum_{k}^{n_{k}} c_{i, j, k},
\end{aligned}
$$

$-i, j, k=$ current index on $\mathrm{x}, \mathrm{y}, \mathrm{z}$ direction for receptor;

$-c_{i, j, k}=$ pollutant concentration in space at receptor, on wind direction, $\left(\mathrm{mg} / \mathrm{m}^{3}\right)$;

$-c_{j, k} c_{i, j}=$ averaged concentration on one direction, $x, k$, respectively.

Table 1. Weather condition classes assigning; correlation of weather conditions defined by cases I - VI, with wind speed

\begin{tabular}{cccccc}
\hline \multirow{2}{*}{ Case } & \multicolumn{5}{c}{ Wind speed $(\mathrm{m} / \mathrm{s})$} \\
\cline { 2 - 6 } & $<2$ & between 2 and 3 & between $\mathbf{3}$ and 5 & between $\mathbf{5}$ and $\mathbf{6}$ & $>6$ \\
\hline I & 1 & $1 ; 2$ & 2 & 3 & 3 \\
II & $1 ; 2$ & 2 & $2 ; 3$ & 4 & 4 \\
III & 2 & 3 & 3 & 4 & 4 \\
IV & 4 & 4 & 4 & 4 & 4 \\
V & 5 & 5 & 5 & 4 & 4 \\
VI & 6 & 6 & 4 & 4 \\
\hline
\end{tabular}




\section{Method}

\subsection{The experimental part. Case study}

Computer simulation of powders dispersion from multiple sources, using the Pol 15sm model, whose basic elements have been previously presented, was applied to 14 point sources, which belong to a number of 5 economical agents in the agroindustrial area of Vaslui city. It was necessary to correctly evaluate the total contribution of a specific pollutant, emitted by the group of sources with this characteristic and to establish the contribution of every source generating a certain type of pollutant, to "show" the total impact of that pollutants concentration at immission, determined in precisely set receiver points.

Encoding of the 14 point sources has been done as follows:

- S1-S3 for SC Stemar SRL Vaslui;

- S4-S9 for SC Termica SA Vaslui;

- S10 for Brick Factory SRL Vaslui;

- S11-S13 for SC Ulerom SA Vaslui; and

- S14 for SC Vascar SA Vaslui.

Six points were set - initial receivers in conjunction with existing fixed point for air quality monitoring from the network of Environmental Protection Agency Vaslui, so we can establish the territorial correspondence below:

- R1 - Point "APM headquarters";

- R2 - Point "Station Vaslui 1 - Public Finance Department Vaslui - urban background station";

- R3 - Point "Vaslui County Hospital";

- R4 - Point "Watewater Treatment Plant";

- R5 - Point "SC Termica SA Vaslui";

- R6 - Point "SC AMC Badotherm SA Vaslui".

As an additional element absolutely necessary for such a model, it is required to enter, in a certain form, the coordinates of emission sources, on West-East and SouthNorth directions, that are cxs and $c y s$, set to a fixed reference point, chosen by user, as well as the coordinates for receptors on West-East and South-North directions, that are $c x r$ and $c y r$, set to the same reference point, called the "reference".

The input data entered in the modelling program in this particular case, to characterize the emissions of pollutants, the point sources and weather conditions are those presented in Table 2 and Table 3, specifying that the classification in stability classes was made considering the instructions in the presentation of Pol $15 \mathrm{sm}$ model, and the

Table 2. Input data - emission sources for Pol $15 \mathrm{sm}$ model

\begin{tabular}{|c|c|c|c|c|c|c|c|c|}
\hline Emission sources & $\begin{array}{c}\text { Geographical } \\
\text { coordinates } \\
\text { latitude/longitude }\end{array}$ & $\begin{array}{c}\mathrm{Q} \\
{[\mathrm{mg} / \mathrm{s}]}\end{array}$ & $\begin{array}{c}\mathrm{Q} \\
{\left[\mathrm{m}^{3} / \mathrm{s}\right]}\end{array}$ & $\begin{array}{c}\mathrm{T}_{\mathrm{f}} \\
{\left[{ }^{\circ} \mathrm{C}\right]}\end{array}$ & $\begin{array}{c}\mathrm{h} \\
{[\mathrm{m}]}\end{array}$ & $\begin{array}{l}\text { cxs } \\
{[\mathrm{m}]}\end{array}$ & $\begin{array}{l}\text { cys } \\
{[\mathrm{m}]}\end{array}$ & $\begin{array}{l}\text { Source } \\
\text { encoding }\end{array}$ \\
\hline $\begin{array}{l}\text { SC Stemar SA Vaslui - } \\
\text { chimney } 1\end{array}$ & $\begin{array}{l}46^{\circ} 37^{\prime} 8.352^{\prime \prime} \\
27^{\circ} 43^{\prime} 61.092^{\prime \prime}\end{array}$ & 0.3138 & 0.0707 & 110 & 12 & 0 & 0 & S1 \\
\hline $\begin{array}{l}\text { SC Stemar SA Vaslui - } \\
\text { chimney } 2\end{array}$ & $\begin{array}{l}46^{\circ} 37^{\prime} 8.352^{\prime \prime} \\
27^{\circ} 43^{\prime} 61.092^{\prime \prime}\end{array}$ & 3.5357 & 0.2898 & 160 & 12 & 0 & 0 & S2 \\
\hline $\begin{array}{l}\text { SC Stemar SA Vaslui - } \\
\text { chimney } 3\end{array}$ & $\begin{array}{l}46^{\circ} 37^{\prime} 8.352^{\prime \prime} \\
27^{\circ} 43^{\prime} 61.092^{\prime \prime}\end{array}$ & 3.3494 & 0.8588 & 100 & 25 & 0 & 0 & S3 \\
\hline $\begin{array}{l}\text { SC Termica SA Vaslui - } \\
\text { chimney } 1\end{array}$ & $\begin{array}{l}46^{\circ} 37^{\prime} 35.4^{\prime \prime} \\
27^{\circ} 43^{\prime} 38.87\end{array}$ & 45.62 & 37.39 & 200 & 80 & 820 & -495 & S4 \\
\hline $\begin{array}{l}\text { SC TermicaSA Vaslui - } \\
\text { chimney } 2\end{array}$ & $\begin{array}{l}46^{\circ} 37^{\prime} 35.4^{\prime \prime} \\
27^{\circ} 43^{\prime} 38.87\end{array}$ & 4.82 & 4.15 & 160 & 60 & 820 & -495 & S5 \\
\hline $\begin{array}{l}\text { SC Termica SA Vaslui - } \\
\text { chimney } 3\end{array}$ & $\begin{array}{l}46^{\circ} 37^{\prime} 35.4^{\prime \prime} \\
27^{\circ} 43^{\prime} 38.87\end{array}$ & 199.3 & 4.91 & 95 & 16.5 & 820 & -495 & S6 \\
\hline $\begin{array}{l}\text { SC Termica SA Vaslui - } \\
\text { chimney } 4\end{array}$ & $\begin{array}{l}46^{\circ} 37^{\prime} 35.4^{\prime \prime} \\
27^{\circ} 43^{\prime} 38.87\end{array}$ & 164.4 & 4.91 & 95 & 16.5 & 820 & -495 & S7 \\
\hline $\begin{array}{l}\text { SC Termica SA Vaslui - } \\
\text { chimney } 5\end{array}$ & $\begin{array}{l}46^{\circ} 37^{\prime} 35.4^{\prime \prime} \\
27^{\circ} 43^{\prime} 38.87\end{array}$ & 118.4 & 1.76 & 95 & 16.5 & 820 & -495 & S8 \\
\hline $\begin{array}{l}\text { SC Termica SA Vaslui - } \\
\text { chimney } 6\end{array}$ & $\begin{array}{l}46^{\circ} 37^{\prime} 35.4^{\prime \prime} \\
27^{\circ} 43^{\prime} 38.87\end{array}$ & 328.9 & 4.91 & 95 & 16.5 & 820 & -495 & S9 \\
\hline $\begin{array}{l}\text { SC Fabrica de caramizi } \\
\text { SRL - chimney } 1\end{array}$ & $\begin{array}{l}46^{\circ} 37^{\prime} 46.25^{\prime \prime} \\
27^{\circ} 43^{\prime} 13.84^{\prime \prime}\end{array}$ & 156.0065 & 2.1488 & 95 & 12 & 1150 & -1050 & S10 \\
\hline $\begin{array}{l}\text { Sc Ulerom SA Vaslui - } \\
\text { chimney } 1\end{array}$ & $\begin{array}{l}46^{\circ} 38^{\prime} 41.52^{\prime \prime} \\
27^{\circ} 43^{\prime} 22.24^{\prime \prime}\end{array}$ & 0.5089 & 0.2827 & 174 & 25 & 1300 & 350 & S11 \\
\hline $\begin{array}{l}\text { Sc Ulerom SA Vaslui - } \\
\text { chimney } 2\end{array}$ & $\begin{array}{l}46^{\circ} 38^{\prime} 41.52^{\prime \prime} \\
27^{\circ} 43^{\prime} 22.24^{\prime \prime}\end{array}$ & 0.5089 & 0.2827 & 174 & 25 & 1300 & 350 & $\mathrm{~S} 12$ \\
\hline $\begin{array}{l}\text { Sc Ulerom SA Vaslui - } \\
\text { chimney } 3\end{array}$ & $\begin{array}{l}46^{\circ} 38^{\prime} 41.52^{\prime \prime} \\
27^{\circ} 43^{\prime} 22.24^{\prime \prime}\end{array}$ & 43.1027 & 0.3848 & 160 & 218 & 1300 & 350 & S13 \\
\hline $\begin{array}{l}\text { Sc Vascar SA Vaslui - } \\
\text { chimney } 1\end{array}$ & $\begin{array}{l}46^{\circ} 37^{\prime} 38.22^{\prime \prime} \\
27^{\circ} 43^{\prime} 65.59^{\prime \prime}\end{array}$ & 2.4504 & 0.6126 & 160 & 45 & 1200 & 100 & S14 \\
\hline
\end{tabular}


Table 3. Input data - receptors for Pol 15sm model

\begin{tabular}{|c|c|c|c|c|c|c|}
\hline Receptors & $\begin{array}{l}\text { Geographical coordinates } \\
\text { latitude/longitude }\end{array}$ & $\begin{array}{c}\mathrm{h} \\
{[\mathrm{m}]}\end{array}$ & $\begin{array}{l}\mathrm{cxr} \\
{[\mathrm{m}]}\end{array}$ & $\begin{array}{l}\text { cyr } \\
{[\mathrm{m}]}\end{array}$ & $\begin{array}{l}\text { Terrain conditions } \\
\text { regarding the source } \\
\text { (rural/urban) }\end{array}$ & $\begin{array}{l}\text { Receptor } \\
\text { encoding }\end{array}$ \\
\hline APM Vaslui & $\begin{array}{l}46^{\circ} 38^{\prime} ' 19.827^{\prime \prime} \\
27^{\circ} 43^{\prime} 21.788^{\prime \prime}\end{array}$ & 1.5 & 2170 & 1000 & urban & $\mathrm{R} 1$ \\
\hline Stația Vaslui 1 & $\begin{array}{l}46^{\circ} 37^{\prime} 55.777^{\prime \prime} \\
27^{\circ} 43^{\prime} 51.307^{\prime \prime}\end{array}$ & 1.5 & 1450 & 800 & urban & $\mathrm{R} 2$ \\
\hline $\begin{array}{l}\text { Vaslui County } \\
\text { Hospital }\end{array}$ & $\begin{array}{l}46^{\circ} 38^{\prime} 18^{\prime \prime} \\
27^{\circ} 45^{\prime} 61^{\prime \prime}\end{array}$ & 1.5 & 2250 & 2700 & urban & R3 \\
\hline $\begin{array}{l}\text { Statia de Epurare } \\
\text { Vaslui }\end{array}$ & $\begin{array}{l}46^{\circ} 37^{\prime} 25^{\prime \prime} \\
27^{\circ} 13^{\prime} 65^{\prime \prime}\end{array}$ & 1.5 & -515 & -1050 & urban & $\mathrm{R} 4$ \\
\hline $\begin{array}{l}\text { SC TermicaA SA } \\
\text { Vaslui }\end{array}$ & $\begin{array}{l}6^{\circ} 37^{\prime} 29.8 \\
27^{\circ} 43^{\prime} 61.092^{\prime \prime}\end{array}$ & 0 & 650 & 0 & urban & $\mathrm{R} 5$ \\
\hline $\begin{array}{l}\text { SC AMC Badotherm } \\
\text { SA Vaslui }\end{array}$ & $\begin{array}{l}46^{\circ} 38^{\prime} 25.84^{\prime \prime} \\
27^{\circ} 42^{\prime} 51.404^{\prime \prime}\end{array}$ & 0 & 2450 & -1500 & urban & R6 \\
\hline
\end{tabular}

simulation was realized taking into account two categories of weather conditions: unstable and highly stable.

The geographical coordinates of the emission point sources considered (S1-S14), as well as the coordinates of receptors R1-R6 have been determined directly on field, using a GPS system. To facilitate calculation and subsequent graphic representations, the reference, (fixed or zero point) with the coordinates: $46^{\circ} 37^{\prime} 8,352^{\prime \prime} / 27^{\circ} 43^{\prime} 61,092$ ", was established in the same place as the sources S1, S2, S3, the Pol $15 \mathrm{sm}$ model not introducing any interdiction or restriction in this regard.

Figure 1 shows the scheme for territorial arrangement of multiple sources and industrial receptors - points, by reporting to a fixed reference point, chosen by the user as input data for the program - reference point with the coordinates of SC Stemar SA Vaslui (S1-S3).

For every receptor, the output data provide by the model as strings of data that indicate:

- local concentration of pollutants due to every emission source;

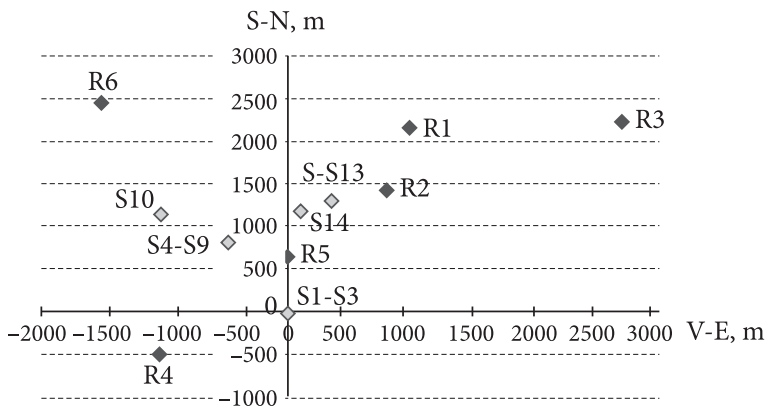

S1-S3 - SC SETMAR SRL R1 - APM headquarter point

S4-S9 - SC TERMICA SRL R2 - Vaslui 1 station - public finances direction point

S10-SC bricks factory SRL R3 - Vaslui county hospital point

S11-S13 - SC ULEROM SA R4 - wastewater treatment plant point

S14 - SC VASCAR SA R5 - SC TERMICA SA Vaslui point

R6 - SC AMC badotherm SA Vaslui point

Fig. 1. Scheme for territorial arrangement of multiple sources and industrial receptor - points, by reporting to a fixed reference point
- total local concentration of the pollutant due to emission of all sources considered.

Data were then selected and processed in table and graphic form, to become more relevant and accessible for analysis and to formulate correct and coherent conclusions.

\section{Results and discussions}

Using the processing facilities of this model tables and graphic representations for 10 different situations depending on weather conditions, have been made. Linking the data and information regarding the emission sources and the receptors with data and information regarding the direction and speed of air currents in Vaslui area, it is observed that:

- prevailing wind in the agroindustrial area of Vaslui is North-West, with an average of $18.5 \%$ out of total per an and higher share (over $50 \%$ of the time) in the hot season;

- second prevailing wind - with a share of only $17.1 \%$ - is the wind from the North;

- in this evaluation of air currents characteristics in the agroindustrial area, a special place is occupied by the atmospheric calm with a share of over $24 \%$ a year's total.

In these conditions, returning to placement scheme of sources and receptors, some assessing guidelines to analyze the modelling results obtained using the simulation program for multiple sources $\mathrm{Pol} 15 \mathrm{sm}$ can be stated:

- with the prevailing wind direction from N-V. R5receptors are partially influenced by emissions of sources S4. S5. S6. S7. S8. S9 and S10 and not at all - influenced by emissions of sources S1. S2. S3. S11. S12 and S13;

- considering the next direction as a share, respectively the wind from $\mathrm{N}$. In this case the receptors R5 and $\mathrm{R} 4$ are influenced by the emissions generated 
by sources S4, S5, S6, S7, S8, S9, S10, S11, S12, S13 and S14;

- in situations of atmospheric calm, characterized by wind speeds under $1 \mathrm{~m} / \mathrm{s}$ and without a definite prevalence of air currents direction (situations frequently accompanied by temperature inversion phenomena), an estimation of the influence shared of each source on the considered receptors cannot be a sufficiently exact. In this case, dispersion conditions must be taken into account, in approximately equal proportions. The direction of air currents in the studied area was also considered in connection with the effect of pollution source on each receptor, respectively - in the order to find the average frequency recorded in one year:

- North-West wind - sources influence on receptors R5;

- South-East wind - sources influence on receptors R6 ;

- North-East wind - sources influence on receptors R4. R5;

- North wind - sources influence on receptors R4. R5;

- South-West wind - sources influence on receptors R1. R2. R3. R5.

Each of the four dominant wind directions has been considered for two atmospheric stability categories, selected as indicated by Pol $15 \mathrm{sm}$ model and according to weather characteristics of the investigated area, namely unstable and stable atmosphere.

Further, analyzing graphics and tables for modelling the dispersion of suspended powders from the multiple sources for ten of these cases, it is found that:

A. If atmosphere is unstable:

For wind direction from $\mathrm{W}$ to $\mathrm{E}$ :

- in receptors R1. R2. R3 and R6 there is no contribution of any powders generating sources. reason for which the total concentration of powders at emission considered in these receiver-points is zero;

- at R4 receptor dust emissions arrive from sources S4. S6. S7. S8. S9. S10;

- at R5 receptor dust emissions arrive from sources S12. S13. S14.

For wind direction from N-W to S-E:

- in receptors R1. R2. R3. R4 and R6 there is no contribution of any powders generating sources. reason for which the total concentration of powders at emission considered in these receiverpoints is zero;

- at R5 receptor dust emissions arrive from sources S4. S5. S6. S7. S8. S9. S10.

For wind direction from S-E to N-W:

- in receptors R1. R2. R3. R4 and R5 there is no contribution of any powders generating sources. Reason for which the total concentration of powders at emission considered in these receiverpoints is zero;

- at R5 receptor dust emissions arrive from S4. S6. S7. S8. S9. S10 and S13.

For wind direction from N-E to S-W:

- at R1 receptor dust emissions arrive from sources S5. S6. S7. S8. S9. S10. S13 and S14;

- at R2 receptor dust emissions arrive from S4. S5. S6. S7. S8. S9. S10 and S14;

- at R3 receptor dust emissions arrive from S6. S7. S8. S9 and S14;

- in receptors R4, R5, R6 there is no contribution of any powders generating sources to the total concentration of powders at emissions, this being considered null.

Figure 2 is a data combination of Table and diagram and summarizes the distribution of powders emissions from the 14 sources in "less unstable" atmospheric conditions.

Reviewing all these observations and correlating them with the results of air quality monitoring, obtained by the surveillance network of the Environmental Protection Agency Vaslui, especially for period of 2000-2009, it is understandable why the annual frequency of powders exceedance registered in monitoring points is so small (not exceeding a maximum of $7 \%$ per year). Although, in this time, all said sources have almost continuously emitted powders with concentrations at emission that do not exceed with a lot the maximum allowed, though it happens.

Basically, the location of network points has partially captured the individual and cumulative influence of selected sources, on one wind direction, that is not the prevailing one (from N-E to S-W).

B. If stable atmosphere:

For wind direction from S-W to N-E:

- in receptors R1. R2. R3. R5 and R6 there is no contribution of any powders generating sources to the total concentration of powders at emissions. this being considered null;

- at R4 receptor dust emissions arrive from S11.

For wind direction from $\mathrm{S}$ to $\mathrm{N}$ :

- in receptors R1. R2. R3. R4 R5. R6 there is no contribution of any powders generating sources to the total concentration of powders at emissions, this being considered null.

For wind direction from $\mathrm{E}$ to $\mathrm{V}$ :

- in receptors R1. R2. R3 and R4 there is no contribution of any powders generating sources to the total concentration of powders at emissions, this being considered null;

- at receptor R5 dust emissions arrive from S1. S2. S3; 


\begin{tabular}{|c|c|c|c|c|c|c|c|c|c|c|c|}
\hline \multicolumn{12}{|c|}{ Powders concentrations generated by the 14 sources to receptors R1-R6 in certain weather conditions } \\
\hline \multirow{3}{*}{$\begin{array}{c}\text { Receptor } \\
\text { No. }\end{array}$} & \multicolumn{4}{|c|}{ Weather conditions } & \multicolumn{7}{|c|}{ Powders concentration $\left[\mu \mathrm{g} / \mathrm{m}^{3}\right]$} \\
\hline & \multirow[b]{2}{*}{$\begin{array}{l}\text { Speed } \\
{[\mathrm{m} / \mathrm{s}]}\end{array}$} & \multicolumn{2}{|c|}{ Wind } & \multirow{2}{*}{$\frac{\mathrm{T}}{\left[{ }^{\circ} \mathrm{C}\right]}$} & \multirow[b]{2}{*}{ Source } & \multirow[b]{2}{*}{$\mathrm{R} 1$} & \multirow[b]{2}{*}{$\mathrm{R} 2$} & \multirow[b]{2}{*}{ R3 } & \multirow[b]{2}{*}{$\mathrm{R} 4$} & \multirow[b]{2}{*}{ R5 } & \multirow[b]{2}{*}{$\mathrm{R} \epsilon$} \\
\hline & & $\begin{array}{c}\theta \\
\text { [degrees] }\end{array}$ & $\begin{array}{c}\text { Pasquill } \\
\text { stability } \\
\text { classes }\end{array}$ & & & & & & & & \\
\hline R1 & 5 & 45 & 1 & 10 & S1 & 0.000 & 0.000 & 0.000 & 0.000 & 0.000 & 0.000 \\
\hline R2 & 5 & 45 & 1 & 10 & S2 & 0.000 & 0.000 & 0.000 & 0.000 & 0.000 & 0.000 \\
\hline R3 & 5 & 45 & 1 & 10 & S3 & 0.000 & 0.000 & 0.000 & 0.000 & 0.000 & 0.000 \\
\hline $\mathrm{R} 4$ & 5 & 45 & 1 & 10 & S4 & 0.000 & 0.004 & 0.000 & 0.000 & 0.000 & 0.000 \\
\hline R5 & 5 & 45 & 1 & 10 & S5 & 0.001 & 0.001 & 0.000 & 0.000 & 0.000 & 0.000 \\
\hline R6 & 5 & 45 & 1 & 10 & S6 & 0.025 & 0.025 & 0.002 & 0.000 & 0.000 & 0.000 \\
\hline \multirow{11}{*}{ 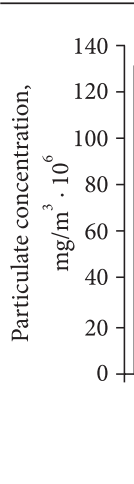 } & & & & & S7 & 0.021 & 0.021 & 0.002 & 0.000 & 0.000 & 0.000 \\
\hline & & & & & S8 & 0.016 & 0.015 & 0.001 & 0.000 & 0.000 & 0.000 \\
\hline & & & & & S9 & 0.042 & 0.042 & 0.003 & 0.000 & 0.000 & 0.000 \\
\hline & & & & & S10 & 0.007 & 0.001 & 0.000 & 0.000 & 0.000 & 0.000 \\
\hline & & & & & S11 & 0.000 & 0.000 & 0.000 & 0.000 & 0.000 & 0.000 \\
\hline & & & & & $\mathrm{S} 12$ & 0.000 & 0.000 & 0.000 & 0.000 & 0.000 & 0.000 \\
\hline & & & & & $\mathrm{S} 13$ & 0.011 & 0.000 & 0.000 & 0.000 & 0.000 & 0.000 \\
\hline & & & & & S14 & 0.001 & 0.006 & 0.001 & 0.000 & 0.000 & 0.000 \\
\hline & & $\square$ & $\square$ & $\square$ & \multirow{3}{*}{$\begin{array}{l}\text { Total } \\
\text { concen- } \\
\text { trations } \\
\text { for } \\
\text { receptor }\end{array}$} & \multirow{3}{*}{0.125} & \multirow{3}{*}{0.118} & \multirow{3}{*}{0.010} & \multirow{3}{*}{0.000} & \multirow{3}{*}{0.000} & \multirow{3}{*}{0.000} \\
\hline & R1 & R3 & $\mathrm{R} 4 \quad \mathrm{R} 5$ & R6 & & & & & & & \\
\hline & Total & ncentrations & per receptor & & & & & & & & \\
\hline
\end{tabular}

Fig. 2. Data and graphical representation for distribution of powders emissions from the 14 sources in "highly unstable" atmospheric conditions

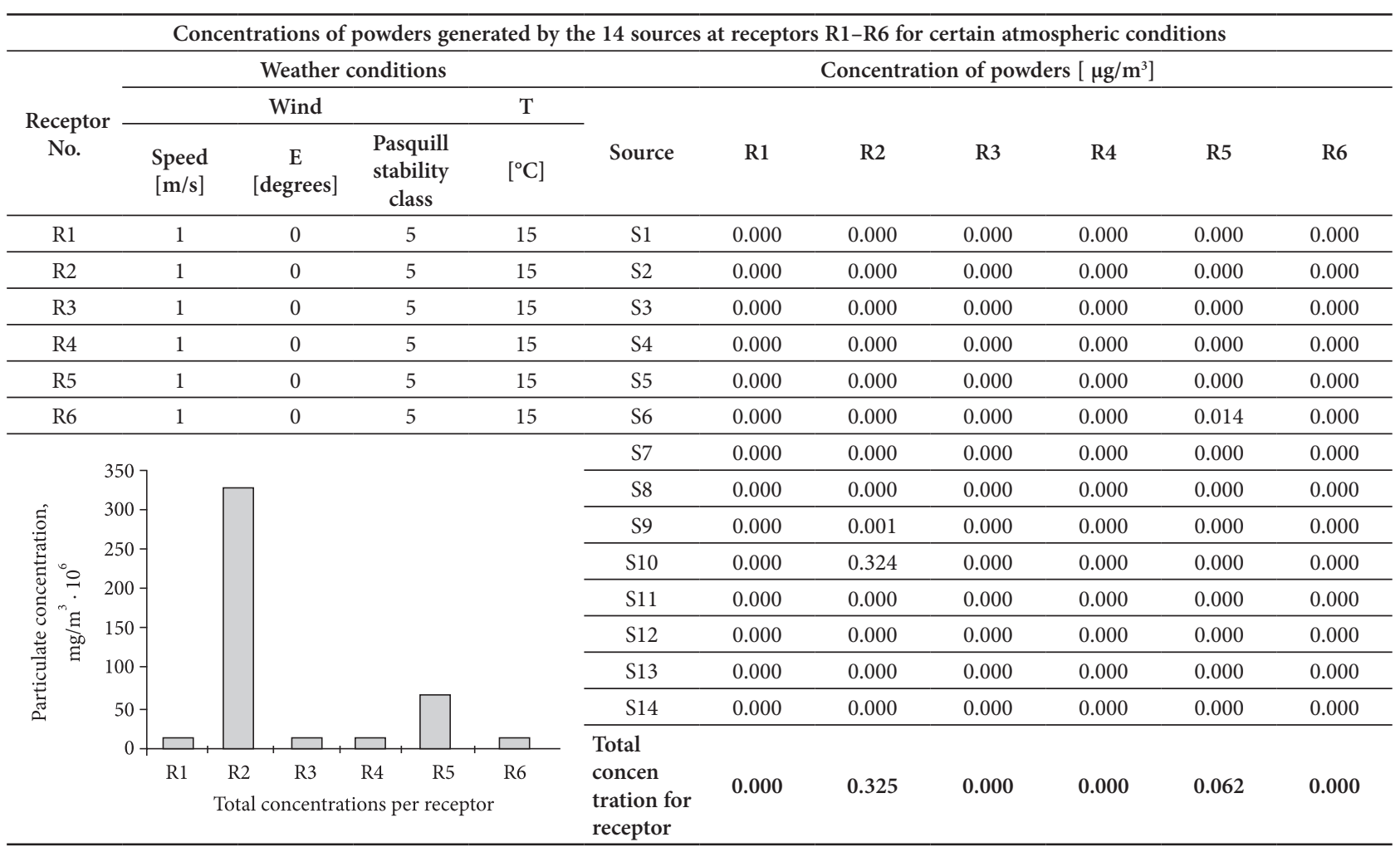

Fig. 3. Data and graphic representation for distribution of powders emissions from 14 sources in atmospheric condition "highly stable" 
- at receptor R6 dust emissions arrive from S9. S10 and S11.

For wind direction from $\mathrm{N}$ to $\mathrm{S}$ (Fig. 3):

- in receptors R1. R3. R4. R6 there is no contribution of any powders generating sources to the total concentration of powders at emissions, this being considered null;

- at receptor R2 dust emissions arrive from S9 and S10;

- at receptor R5 dust emissions arrive from S6. S7. S8. S9.

Figure 3 is a combination of Table and diagram that summarizes the distribution of powders emissions from the 14 sources in "highly stable" atmospheric conditions.

In terms of influence areas and the intensity of impact made by every point source, it can be concluded that:

- total concentrations on receptors from all 14 sources, calculated with the simulation program Pol $15 \mathrm{sm}$ for multiple emission sources, are well below maximum admitted limit, and are between 0.004 and 0.076 micrograms/cubic meter;

- the calculations were done for the majority of weather conditions encountered in Vaslui city - from atmospheric calm to strong wind - for both models. In none of the situations maximum allowed concentrations have been reached;

- in any case, maximum concentrations at emission are, without exception, well below maximum allowed limits for suspended powders;

- results of dispersion of suspended powders that contain heavy metals using the simulation program Pol $15 \mathrm{sm}$ are consistent with those determined experimentally by the Environmental Protection Agency Vaslui over time and are a justification for reduction of monitoring points for air quality.

\section{Conclusions}

1. Dispersion modelling has been studied for 14 point sources of emission, from 5 economic agents: SC Stemar SRL Vaslui, SC Termica SA Vaslui, Fabrica de cărămizi SRL Vaslui, SC Ulerom SA Vaslui and SC Vascar SA Vaslui, with an original mathematical model of pollutants dispersion, which is the Pol $15 \mathrm{sm}$ model. Based on this model, a simulation program for a chosen pollutant's dispersion, emitted simultaneously by multiple sources has been made. As a result, pollutant concentrations at emission for many set receptors has been obtained.

2. The maximum number of usable sources in the same time (15) by the simulation program, as well as the maximum number of receptors that can be set (15) covers the needed investigations for industrial platforms. This, together with the fact that the model implies a plain input data, easy to introduce and accomplish, recommends the use of the model for very simple flat-land scenarios.

3. The POL15sm model application, as a tool for analyzing the problems of air pollution, provides a significant reduction in both cost and time than the application for other models (e.g. AERMOD) making possible the estimation of human activities' impact on the environment cheaper and faster.

\section{References:}

Ani, E.-C.; Cristea, V. M.; Agachi, P. S. 2012. Mathematical models to support pollution counteraction in case of accidents, Environmental Engineering and Management Journal 11: 13-20.

Baldauf, R.; Watkins, N.; Heist, D.; Bailey, C.; Rowley, P.; Shores, R. 2009. Near-road air quality monitoring: factors affecting network design and interpretation of data, Air Quality, Atmosphere \& Health 2(1): 1-9. http://dx.doi.org/10.1007/s11869-009-0028-0

Branquinho, C.; Gaio-Oliveira, G.; Augusto, S.; Pinho, P.; Máguas, C.; Correia O. 2008. Biomonitoring spatial and temporal impact of atmospheric dust from a cement industry, Enviromental Pollution 151(2): 292-299. http://dx.doi.org/10.1016/j.envpol.2007.06.014

Budianu, M.; Macoveanu, M. 2010. Modeling of dispersions of powder emissions from the industrial area of Vaslui, Bulletin of the Polytechnic Institute of Iasi. Section of Chemistry and Chemical Engineering LVI(LX): 129-138.

Candelieri, A.; Giordani, I.; Testa, P.; Arosio, G.; Archetti, F. 2012. A Markov-based model to forecast emergency hospital admissions due to air pollution: the Lenvis project approach, Environmental Engineering and Management Journal 11: 999-1008.

Carpentieri, M.; Kumar, P.; Robins, A. 2011. An overview of experimental results and dispersion modelling of nanoparticles in the wake of moving vehicles, Environmental Pollution 159: 685-693. http://dx.doi.org/10.1016/j.envpol.2010.11.041

Gaba, A. 2010. Air pollution reduction by using of low NOx burners for furnaces and boilers, Environmental Engineering and Management Journal 9: 165-170.

Hanna, S. R. 1981. Applications in air pollution modelling, in FTM; van Dop, H. (Eds.). Atmospheric turbulence and air pollution modelling. Nieuwstadt: D. Reidel Publishing company, 275-310.

Huang, Z.; Jin, G.; Wang, X. 2011. Numerical simulation applied for unsymmetrical dimethylhydrazine propellant gas dispersion based on CFD technology, Environmental Engineering and Management Journal 10: 971-974.

Mezdrea-Cojocareanu-Pata, I.; Pata, S. M.; Macoveanu, M. 2010. Biomonitoring of atmospheric pollution of $\mathrm{Fe}$ and $\mathrm{Zn}$ using native epigeic mosses, Environmental Engineering and Management Journal 9: 1217-1225.

Miclaus, C.; Dezsy, S.; Nicu, M. 2006. Passive samplers - checking method in the air quality control network, Environmental Engineering and Management Journal 5: 1333-1340.

Moreira, D. M.; Vilhena, M. T.; Tirabassi, T.; Buske, D.; Pinto da Costa, D. 2010. Comparison between analytical models to simulate pollutant dispersion in the atmosphere, International Journal of Environment and Waste Management 6: 327-344. http://dx.doi.org/10.1504/IJEWM.2010.035066 
Nagacevschi, V.; Macoveanu, M. 1994. Modeling of pollutants dispersion into the atmosphere, in Conference: Progress in Chemistry and Chemical Technology, 27-29 October, 1994, Polytechnic Institute of Iasi, Iasi, Romania, 41-47.

Nagacevschi, V.; Macoveanu, M. 1995. Modeling of dispersion for pollutants emitted into the atmosphere from multiple sources, in The 5th National Colloquium for Atmosphere Protection, 15-17 November, 1995, SOROPA, București, Romania, 64-70.

Nagacevschi, V.; Macoveanu, M. 1996. Dynamic simulation of air pollution, in National Symposium: Technologies With Low Environmental Impact for the Tanning of Hides and Skins, 6-8 June, 1996, Technical University of Iaşi, Iasi, Romania, 39-46.

Nagacevschi, V.; Macoveanu, M.; Peiu, N. 1997. Model for the air dispersion of a pollutant, Bulletin of the Polytechnic Institute of Iasi. Technical University "Gheorghe Asachi” Iaşi, LI, 23-31.

Nagacevschi, V.; Macoveanu, M. 2002. Contract: the study of dispersion for pollutants emitted into the atmosphere at the site of Bread Factory No.1. Galați belonging to S.C. GALMOPAN. Galați. Execution - S.C. REDICOM S.R.L. Iaşi. 2002, 6-12.

Nisulescu, C.; Călinoiu, D.; Timofte, A.; Boscornea, A.; Talianu, C. 2011. Diurnal variation of particulate matter in the proximity of Rovinari fossil-fuel power plant, Environmental Engineering and Management Journal 10: 99-105.

Pasquill, F. 1961. The estimation of the dispersion of windborn material, Meteorological Magazine 90: 33-49.
Popescu, F.; Ionel, I.; Talianu, C. 2011. Evaluation of air quality in airport areas by numerical simulation, Environmental Engineering and Management Journal 10: 115-120.

Radulescu, C.; Prisecaru, T.; Mihaescu, L.; Pisa, I.; Lazaroiu, G.; Zamfir, S.; Vairenu. D.; Popa, E. 2010. Researches on the negative effects assessment (slugging, clogging, ash deposits) developed at the biomass-coal co-firing, Environmental Engineering and Management Journal 10: 17-26.

San Jose, R. 1997. Sensitivity study of dry deposition fluxes in ANA air quality model over Madrid Mesoscale area - measurements and modelling in environmental pollution. Southampton, Boston. 119-129.

Smaranda, C.; Gavrilescu, M. 2008. Migration and fate of persistent organic pollutants in the atmosphere - a modelling approach, Environmental Engineering and Management Journal 7: 743-761.

Stătescu, F.; Cotiusca-Zauca, D. 2006. Heavy metal soil contamination, Environmental Engineering and Management Journal 5: 1205-1213.

Ştefan, S.; Radu, C.; Belegante, L. 2013. Analysis of air quality in two sites with different local conditions, Environmental Engineering and Management Journal 12: 371-379.

Vătăşescu, M. M.; Diaconescu, D.; Duță, A.; Burduhos, B. G. 2011. Atmospheric pollution evaluation in Brasov Romania based on turbidity factor analysis, Environmental Engineering and Management Journal 5: 251-256.

Mihaela BUDIANU. PhD student in Department of Environmental Engineering and Management, Faculty of Chemical Engineering, Technical University of Iasi. Publications: author/co-author of 10 scientific papers. Research interest: environmental engineering.

Valeriu NAGACEVSCHI. Professor at the Faculty of Chemical Engineering, Technical University of Iasi (retired).

Matei MACOVEANU is a Consultant Professor at the Faculty of Chemical Engineering and Environmental Protection Iasi. In the 44 years of teaching and scientific activity has received numerous awards for his inventions ( 31 patents obtained in the country and abroad). He is the Founder of the international academic journal Environmental Engineering and Management Journal, initiator of the $\mathrm{PhD}$ establishment in Environmental Engineering, from the Technical University "Gheorghe Asachi" of Iasi. Publications: author/co-author of 23 books published in central publishing, over 200 scientific papers published in specialized periodicals in the country and abroad. 